\title{
Wind power planning in France (Aveyron), from state regulation to local planning ${ }^{1}$
}

\author{
Alain Nadaï ${ }^{2}$ \\ CIRED - Centre International de Recherche sur l'Environnement et le Développement \\ Jardin Tropical \\ 45 bis avenue de la Belle Gabrielle \\ 94736 NOGENT-SUR-MARNE Cedex \\ E-mail : nadai@centre-cired.fr \\ Olivier Labussière ${ }^{3}$ \\ Université de Pau et des Pays de l’Adour, France \\ Laboratoire Société Environnement Territoire \\ IRSAM - 64000 Pau \\ E-mail : olivier.labussiere@etud.univ-pau.fr
}

\footnotetext{
${ }^{1}$ This paper is available at: http://dx.doi.org./10.1016/j.landusepo. 2008.10.018

${ }^{2}$ Please send any correspondence to the address of this author.

${ }^{3}$ Present address: CIRED - Centre International de Recherche sur l'Environnement et le Développement, Jardin Tropical, 45 bis avenue de la Belle Gabrielle, 94736 NOGENT-SUR-MARNE Cedex.
} 


\title{
Wind Power Planning in France (Aveyron), from State Regulation to Local Planning
}

\begin{abstract}
The development of wind energy in France presents an exemplary case of contrast between the policy instrument and its effectiveness in terms of installed wind power capacity. After 7 years of one of the highest feed-in tariffs in the world, the installed capacity in France is still very low. This is notably due to a diffuse pattern of administrative landscape protection which impacts on the construction of wind power potential. In turn, the pace of wind power development can be understood only by looking in more detail at the way in which landscape is dealt with in local planning processes. This paper examines the question using the case of Aveyron in southern France. We follow the shifting ways in which landscape is enrolled in wind power planning, in a context where new planning instruments favor an incipient decentralization in wind power policy. The case points to a change in both the networks and the concepts involved in the design of landscape representations that underlie the construction of wind power potential. We show that this change has been forced by the far-reaching and decentralized visual impacts of wind power technology, suggesting that technology is recomposing the social as part of its development process and questioning the very meaning and perception that is given to landscape.
\end{abstract}

\section{Keywords}

Wind power - Planning - Landscape - France - Decentralization 


\section{Résumé}

Le développement de l'énergie éolienne en France illustre de façon exemplaire l'écart qui peut survenir entre l'instrument d'une politique publique et son efficacité. Malgré sept années de soutien à la filière éolienne par un tarif d’achat parmi les plus élevés au monde, les capacités installées restent très faibles dans l'hexagone. Cela est notamment du à une tradition administrative de protection du paysage dont l'influence est significative sur la définition des potentiels éoliens. Aussi, il est important d'examiner comment les enjeux de paysage sont intégrés aux processus de production des planifications éoliennes; ce que nous proposons d'étudier à partir du cas de l'Aveyron, dans le sud de la France. L'analyse porte en particulier sur les étapes de conception et les jeux d'acteurs qui soustendent la planification éolienne aveyronnaise. Elle s’intéresse aussi à la façon dont celle-ci s'ouvre progressivement à une approche davantage décentralisée via de nouveaux outils, comme les zones de développement éolien. Ce cas montre combien les concepts et les réseaux qui sous-tendent les représentations paysagères mobilisées pour définir un potentiel éolien sont cruciaux ainsi que la nature des enjeux qui accompagne l'évolution de celles-ci. In fine, cet article insiste sur le fait que l'éolien, en tant que technologie décentralisée ayant une forte présence dans le paysage, soulève des processus de recomposition du social qui sont inhérents au développement de la technologie elle-même ; ce qui interroge quant aux moyens permettant de tenir compte des perceptions et des usages attachés au paysage.

\section{Mots-clefs}

Eolien - planification - paysage - France - décentralisation 


\section{Introduction}

By the end of 2006, wind energy totaled up to $48 \mathrm{GW}$ of installed capacity in the European Union (Observ'er, 2007a). About 10 years ago, researchers pointed to a changing agenda for renewable energies (Walker, 1995), including considerations concerning issues of planning the development of wind energy (McKenzie Hedger, 1995). Since the installed wind power capacity mirrored the type of financial instruments underlying wind power policies, the debate about these policies remained focused on the instruments (e.g., Haas et al., 2004 for a synopsis of this debate). This has recently changed and the policy debate has become wider. A broader set of conditions underlying wind power development is now being considered again, including the planning regime, the local/cultural context (McLaren Loring, 2007; Toke, 2005, Toke et al., 2008), turbine ownership (Devine Wright, 2005; McFaden and Warren, this issue), and the propensity of policy schemes to foster a societal engagement in policy design and implementation (Breukers et al., 2007, Cowell et al., 2007, Szarka, 2006).

France is an exemplary case of contrast between policy instrument and installed capacity. After 7 years of one of the highest feed-in tariffs in Europe (Ministry of Economy, 2000b, 2001, 2006a), the installed capacity is still very low (1.8 GW) compared with other countries which have relied on the same type of tariffs: Spain (11.6GW), Germany (20.6GW) and Denmark (3.14GW) (figures from the end of 2006, Observ'er, 2007a). Institutional lock-in into nuclear energy is one reason that explains the French case (Szarka, 2007). Another reason is a diffuse pattern of administrative landscape protection which impacts on the construction of wind farms. Landscape is among the principal reasons invoked by the local administration for rejecting projects . On average, about $20 \%$ of wind power applications were denied construction permits in 2005 (Minefi, 2006), a proportion which varied from 0\% to 56\% depending on the region. Local opposition was not systematically involved in these results, since wind power has been opposed on a strong and regular basis by civil society only in some tourist and secondary residence areas or in places where landscape is particularly valued (e.g., Provence Alpes Côtes d'Azur, Basse Normandie, Rhône Alpes). Elsewhere, the pace taken by wind power development can only be understood by looking in more detail at the way in which landscape was enrolled by the administration in planning processes.

Representations of nature and of the environment have held scholars' attention in relation to wind power. Analysts have shown how landscape is endowed with a moral dimension in relation to energy consumption patterns (Pasqualetti, 2000) and how nature / rural space is at the core of discourse coalitions in wind power conflicts (Woods, 2003, Szarka, 2004, Warren et al., 2005). Landscape culture - meaning the ways in which landscape is traditionally accounted for by lay persons, landscape protection organizations and local/national administration in different societies - has been pointed to as one factor underlying wind power development (Coles and Taylor, 1993; Danielsen, 1995, Toke et 
al., 2008), but detailed attention has also recently been given to landscape representations in relation to the planning processes (Burall, 2004; Cowell, this issue; Wolsink, forthcoming).

Because of their visual impact, industrial turbines are rarely compatible with the current representations and categories of European landscapes (Selman, 2007). While wind power developments have good chances of meeting with more acceptance in parts of the territory characterized by extended industrial landscapes or the absence of heritage landscapes, these developments are always potentially controversial. Three routes are then open to policy makers and planners. The first one consists of accepting a limited development (route 1). The second is to have recourse to the administrative hierarchy and try to impose quantitative targets on local and regional authorities. As Richard Cowell illustrates using a Welsh study (Cowell, this issue), such metagovernance tends to reinforce existing landscape patterns by targeting developments on less valued landscape area, ultimately raising issues of environmental justice (route 2). The third route consists in approaching wind power issues as an occasion to reconsider the rules governing landscape valuation (route 3). This means establishing processes and procedures which would allow for the "creation of wind power landscapes”, as advocated by the French Agency for Energy. In trying to do so, the difficulty is that we do not know what type of landscape wind power could compose, so that it is up to policy and planning processes to set the conditions for the emergence of corresponding landscape representations. In other words, if wind energy is to make a significant contribution as an alternative to current energy patterns, we should not try to fit turbines into existing landscapes but rather to set up processes by which new landscape representations might arise along with wind power developments and make the new landscapes sustainable. The key question is then how to define such processes.

French institutions have followed several routes in developing wind power. Despite repeated announcements of significant targets (Ministry of Economy, 2006b), the national level seemed implicitly to accommodate itself to the slow pace of wind power development (route 1$)^{4}$. By contrast, the local level was often faced with a "wind dash" and did its best to regulate developments. This was done through a mixture of hierarchy imposing conformity with existing landscape protection regulations (route 2) and ad hoc, more open processes looking for ways of defining new compatibilities between landscapes and wind power (route 3). Only recently (that is, 7 years after the adoption of the French fixed tariffs) did the national level implement a planning framework (Ministry of Energy, 2005) with great but uncertain potential: wind power development zones. As things are, French WPDZ might foster bottom-up planning and what could be called a French variant of

\footnotetext{
${ }^{4}$ This was confirmed by French President Sarkozy's recent speech at the conclusion of the “Grenelle de l’Environnement”. The French President said that heritage landscapes should be protected and wind power preferably located in industrial areas (See: http://cdurable.info/Grenelle-de-l-environnement-le.html, consulted dec.12, 2007). Clearly, industrial areas do not offer enough space for installing the 23GW (about 11000 turbines) that are announced by the French authorities (target adopted in the final report of the Grenelle).
} 
"decentralization" ${ }^{5}$, but they also might well boil down to hierarchical decision-making under the authority of the local state (i.e., department prefects) ${ }^{6}$ (Nadaï, 2007a). Success in this decentralization depends on whether or not the relation between local state representatives and other local actors can be re-organized so as to make room for genuine cross-fertilization in the design of these zones. Only on this condition can WPDZ depart from mere hierarchical planning and landscapes be processed in a way that allows for the emergence of new landscape representations.

This paper examines the question using the case of Aveyron in southern France. We follow the shifting ways in which landscape is enrolled in wind power planning in a context where WPDZ favor an incipient decentralization in wind power policy. The case points to a change in both the concepts and networks that lead to the landscape representations underlying the construction of wind power potential. We show that this change is forced by the far-reaching and decentralized visual impacts of wind power technology, suggesting that technology is recomposing the social as part of its development process and questioning the very meaning and perception that is given to landscape.

The first part of the paper presents the materials and method. The second part provides background information about Aveyron wind power before proceeding to analyze Aveyron wind power planning. The third part discusses the results by placing them in perspective with other French regions and the international wind power planning literature.

\section{Materials and methods}

The Aveyron planning process has been analyzed on the basis of written and graphic documents, observation in a public meeting and face-to-face qualitative interviews (27 interviews) with the different actors. Interviews have been undertaken in three campaigns during the fall of 2006 and the spring and the summer of 2007; they aimed at tracing wind power development and the planning process in Aveyron, with a focus on landscape issues.

The national perspective on wind power policy is based on core policy documents, some face-to-face interviews with key players in wind power development and policy making at the national level as well as qualitative phone interviews with the (22) regional field services of the French Ministry for the

\footnotetext{
${ }^{5}$ Our approach overlaps with other approaches to multi-level governance, such as Smith (2007), which indicates the emergence of a regional dimension in English renewable energy policy. Our reading of the French case in this paper is through landscape.

${ }^{6}$ The French levels of governance do not overlap with the ones usually covered by the Anglo-Saxon terminology. For the sake of simplicity, we use a terminology found in an international description of the French administrative organization (OECD, 2006): Community or Municipality (ies) refer to the French “commune” or "municipalité”, an entity more or less corresponding to the English parish or local government, albeit it is not a governmental administration in France; mayors or local councillors are their elected representatives; intercommunality(ies) refers to a group of communities structured as a territorial entity so as jointly to organize public services such as waste management, public transportation ... ; department refers to the French “départment”, a sub regional administrative division; region refers to the French "région"; central / national government or State refers to the central administration; ministerial fields services refers to the regional offices of departments/ministries, region and department prefects are local representatives of the State.
} 
Environment (DIREN) (fall 2006). DIREN are part of the local planning processes. Their notification on project assessments is supposed to reflect other ministerial field services and is that which prefects most often heed when making their final decisions.

Our approach draws upon landscape theory and science studies. Landscape theory has shown that landscape is a complex and multifaceted cultural and political process (Hirsch et al., 1995; Olwig, 2002). It is relevant to a visual and symbolic representation, to a scenery (Cosgrove et al, 1988). It is also a dwelling, a place to live in, a place for debated identities and contested power (Bender, 1998), a place through which power is conceived and enacted (Mukerji, 1997). In the French context, the emphasis on the cultural and scenic landscape dominant since the mid-1990s (Roger, 1997) is progressively making room for more encompassing approaches, including consideration of the way in which people experience their “daily” landscape (Bigando, 2004).

In this paper, landscape representations point to the way in which landscape is part of the planning process. We are as much interested in the materiality of these representations (i.e., graphic, written, verbal or other) as in the relations and social networks they establish by their tendency to convey meaning in specific areas, to circulate through wide dissemination and finally to orient the course of the planning process. In approaching these representations, we consider them as part of a social process of planning and re-composition. We are interested in the many ingredients contributing to their construction, be they human or not (Latour, 2003, 2005; Nadaï, 2007b), as well as in the way in which technology is re-composing the social by questioning existing, stabilized representations (e.g., Marvin, 1988).

\section{Aveyron wind power and the uncertain emergence of new landscape representations}

\section{Aveyron wind power: an overview}

Wind power development started in Aveyron in 19997. The administrative assessment and the development of the first project was the occasion to set up the MISAP, an ad hoc commission including various ministerial field services - e.g., roads and infrastructures (DDE), environment (DIREN), industry (DRIRE), architecture and cultural heritage (SDAP) - as well as nonadministrative entities such as the Regional Park (Parc Naturel Régional des Grands Causses, PNRGC), the Aveyron Council for Architecture, Urbanism and Environment (CAUE), and the local branch of the national bird-watching organization (LPO). Right after this first project, the adoption of the French tariffs in 2000 was followed by a wind dash which lasted until the present (cf. Table 1). In the absence of any national scheme, the Aveyron administration started to develop a local planning scheme, as did many other French regions. The work started in 2000 and the final document was

\footnotetext{
${ }^{7}$ For a detailed account and analysis of French wind power policy development, see Nadai, 2007a.
} 
issued in 2005 (Préfecture de l'Aveyron, 2005). The working process resulted in narrowing down the MISAP to the core ministerial field services as the main players: DDE, DIREN, DRIRE and SDAP.

Table 1: Projects submitted for construction permit between 1999 and 2006 (source DDE 12, Fall 2006)

\begin{tabular}{|l|c|c|c|c|c|c|c|c|}
\hline Year & $\mathbf{1 9 9 9}$ & $\mathbf{2 0 0 2}$ & $\mathbf{2 0 0 3}$ & $\mathbf{2 0 0 4}$ & $\mathbf{2 0 0 5}$ & $\mathbf{2 0 0 6}$ & $\begin{array}{c}\text { End of } \\
\mathbf{2 0 0 6}\end{array}$ & Total \\
\hline Intentions of projects (nb) & - & - & - & - & - & - & 56 & 56 \\
\hline Construct. permits (nb) & 1 & 3 & 8 & 21 & 7 & 11 & - & 53 \\
\hline Turbines (nb) & 12 & 15 & 46 & 90 & 36 & 47 & - & 246 \\
\hline Capacity (MW) & 5.6 & 1.4 & 82 & 238 & 66 & 109 & - & 502 \\
\hline
\end{tabular}

In 2003, a new law in urbanism (Ministry of Interior, 2003) extended the usual authorization procedures to wind power development: construction permits, impact studies and public inquiry were supposed to provide the administration with the necessary information for assessing the impacts of individual projects (i.e., noise, environment, landscape and local acceptance). The DIREN was put in charge of the final administrative notification (approval, adjustments or negative notification), with possible consultation of other parties (e.g., DDE, DRIRE, SDAP, PNR, etc.). The commissar in charge of the public inquiry provided a second and separate notification, based on the views of local citizens. Citizens could also directly petition the department Prefect. Notifications and petitions were communicated to the prefect for final decision.

In 2005, a new French energy programming law introduced the WPDZ, due for implementation in July 2007 (Ministry of Energy, 2005a). By 2007, the Aveyron administration had already been faced with the limits of authorization procedures and was being confronted with the limits of its own planning scheme. The implementation of WPDZ provided local actors, especially the PNRGC, with an opportunity to enter into the planning process again and innovate the approach to wind power landscapes.

In what follows, we analyze the reach and limits of the Aveyron administrative approach to landscape, considering successively the ways in which authorization procedures and the Aveyron planning scheme have operated and performed. We then examine the ways in which WPDZ might change this approach by opening the planning process to local actors. 


\section{Reach and limits of the "administrative" landscapes}

\section{- Construction permits and the limits of "monumental landscape"}

Wind power construction permits are granted by various ministerial field services, including the SDAP, which is most often consulted because it has the mandate to preserve cultural landscapes and surroundings of historical monuments/protected sites $^{8}$. Generally, local administrations agree on the limits of construction permits when it comes to wind power. A "landscape chapter" had been introduced into these permits (Ministry of Environment, 1993), mainly dealing with the visual impact of constructions on their "surroundings", a notion which proved to be limited and confronted the SDAP with increasing difficulties with respect to wind power.

Successive laws in the tradition of monumental landscape have endowed the SDAP with the power of making a binding notification valid within a (500m radius) state-declared delimited area in the vicinity of protected monuments and sites, which can be expanded under specific conditions in order to take into account the topography and the local characteristics of a place ${ }^{9}$. Beyond this area, the SDAP's notification is only advisory. This geography of "monumental landscape" triggered a two-tier strategy in relation to wind power. Following the usual protection algorithm, the Aveyron SDAP first introduced buffer zones of $5 \mathrm{~km}$ radius around major Aveyron landmarks as part of the wind power planning scheme. One year after making the scheme public, the SDAP concluded that this was insufficient to prevent the far-reaching visual impact of wind power and turned to an alternative strategy frequently used by project opponents when appealing to the administrative court. The "R11121”, named according to an article of the urban code, allows opponents to oppose projects which might "impact on the character or the interest of surrounding place, sites, landscapes or monumental perspectives...”. While R111-21 allows the SDAP to reach beyond state-declared delimited areas, it is considered by the administration to be a "landscape without monument" (sic) strategy. In other words, R111-21 is a stopgap strategy, for in applying it the SDAP renounces the institutional power attached to a "monumental landscape". Indeed, the R111-21strategy requires opponents to qualify their opposition with relevant landscape observations. As stated by a DIREN official from another French region, "opposable" ${ }^{10}$ landscapes - meaning state-declared delimited areas, protected and classified landscapes - might sometimes be appropriate and offer a ready-made legal basis for opposition. In most cases, however, "non-opposable" landscapes - i.e., those landscapes without authoritative, nationally designated features - are the ones concerned and remain the most difficult issue when it

\footnotetext{
${ }^{8}$ « Sites inscrits » et « sites classés » are the two types of protected areas under heritage considerations. "Inscription” implies a will to keep the site unchanged, whereas "classification” only imposes a duty of informing the administration of any project that could impact on the classified area. These notions were introduced by the Law of April 21,1906, finalized under the Law of May 2' 1930 and written into the French code for the environment. The 1930 law is usually referred to as in the tradition of "monumental landscape": it extended to landscape a type of protection that was already in place for monuments, thus implicitly "valuing” landscape as if it was part of the French monument heritage.

${ }^{9}$ For a detailed account, see: http://www.culture.gouv.fr/culture/regions/sdap/sdap.htm

${ }^{10}$ In French, an argument is "opposable” if it can be oppose to a third party in court.
} 
comes to wind power, since they do not offer a ready-made legal basis or even landscape characterization that could serve as a basis for arguing cases.

\section{- Impact studies, the limits of "visual landscape"}

In principle, impact studies are processed by the DIREN and are supposed to extend beyond the immediate surroundings and protected landscapes. The impact on landscape is simulated through sketches, cross-sections and photomontages presenting views before and after turbine construction. One issue for the administration is then to judge whether or not these representations convey a good sense of the visual impact of the project. If cross-cuts are "more reliable", photomontages "can be tricked" and display shots that "taken from two or three meters aside [...] would have been completely different" (a DIREN official). Yet the decentralized pattern of wind power development and the increasing number of permits for processing, force the DIREN to rely on the material provided by developers. Increased mobility of civil servants in search of career advancement tends to widen the gap between what administrators actually know about "their" local territory and what they should know in order to be able to judge from a distance. The far-reaching impact of wind power makes this gap even more critical. Wind power developers sometimes acquire a better knowledge of the territory than the local administration and impact studies become "a little like archeological finds; they reveal [to the administration] the richness of the territory” (a DIREN official).

While the Midi Pyrénées DIREN seems willing to take account of proximity issues, based (for instance) on "elements [of perception of the impact of the project] from where people live, from where they circulate, from where they walk...”, this is rarely the case. In methodology, impact studies tend to emphasize the scenic landscape, and this even more so in the case of wind power, since far-reaching impacts demand abstraction in order to be grasped:

\footnotetext{
"Working on wind power requires us to work on a scale we are not used to [...]. With wind power, our approach to landscape is driven by the issues of impact and co-visibility [...]. Usually, for instance for a small architecture project, if I wanted to know from where the building would be visible, I would go there, I would stand there and look around. On the principle of reciprocity - 'I see you, you see me' - [...] I could see all the places from which the project would be visible [...]. This no longer works for a 120-meter turbine, potentially visible from 17 kilometers around [...]." (Local landscape consulting office, December, 2006).
}

Software that was used for big infrastructures (i.e., towers, high poles, etc.) has been adapted to wind power and is in common use for mapping areas from which a future turbine will be visible. This abstract mapping - it takes account only of topography - is the framework the administration uses in zooming in on specific areas where "co-visibility" will eventually be more deeply explored. In principle, other wind power projects should be considered in the exercise, so as to avoid cumulative effects of development. Impact studies, however, proved limited in this task, especially for projects that were planned but not yet installed, since developers can hardly ask competitors for specifics on future developments (i.e., number of turbines, type, display, etc.). Belvederes and panoramic viewpoints are then prioritized, with one consequence (emphasized by the PNRGC) being that 
landscape impact analysis proceeds in a top-down manner and considers issues of big/faraway/scenic landscape before issues of proximity. As in the case of permits, "non-opposable” landscapes are put to one side.

\section{- Public inquiry (“public interest”) as a marginal landscape adjuster}

Residents are supposed to raise proximity issues during the public inquiry. During this last phase of the authorization procedure, the impact study is posted in the town hall for a month and citizens are invited to make comments (i.e., petitions, subjective appreciation, elements of counter-expertise).

There seems to have been a widening gap in Aveyron between a growing local opposition to wind power and the overall approval of wind power projects by the commissars in charge of the public inquiries. In 2000, only one individual farmer, whose sheep were grazing near the future turbines, opposed the first wind power project. By 2007, 4 pro and 10 anti-wind power NGOs were officially registered in Aveyron ${ }^{11}$. While local opposition has been growing, notably in relation to the increasing density of wind power projects (e.g., on Monts Lévezou), the 29 public inquiries which have taken place in relation to wind power projects have all been concluded positively (cf. Table 2). Some inquiries recommended adapting the projects (i.e., reducing the number of turbines or moving some turbines), and this was the case even when the MISAP delivered a negative notification on the project as a whole.

Table 2: Outcomes of the permit instructions in Aveyron since 2002 (DDE 12, Fall 2006)

\begin{tabular}{|c|c|c|c|c|}
\hline & $\begin{array}{l}\text { Public } \\
\text { inquiries }\end{array}$ & $\begin{array}{l}\text { MISAP } \\
\text { advice }\end{array}$ & $\begin{array}{l}\text { Prefect } \\
\text { decision }\end{array}$ & Comments \\
\hline Positive & 29 & 20 & 24 & $\begin{array}{l}\text { - } 6 \text { projects judged as being in co-visibility with other projects, } \\
-1 \text { appeal to the administrative court. }\end{array}$ \\
\hline Negative & & 9 & 8 & $\begin{array}{l}\text { - } 2 \text { incompatibilities with POS, } \\
\text { - } 1 \text { negative notification from the Commission for Sites, Perspective and Landscapes } \\
\text { (CSPL), } \\
\text { - } 2 \text { for proximity to infrastructures (housing, road), } \\
-3 \text { appeals to the administrative court. }\end{array}$ \\
\hline Absent & 3 & 3 & & \\
\hline Total & 32 & 32 & 32 & \\
\hline
\end{tabular}

One interview with a commissar and the analysis of the related inquiry showed that a few wellarticulated favorable petitions were used in a critical way in order to rationalize a final "approval with recommendation" when about 300 unfavorable but less well-articulated individual petitions were also submitted. In such a case, the strategic use of the principle "silence gives consent" on the part of notional supporters of wind power was used to give the few but well-articulated petitions more weight.

\footnotetext{
${ }^{11}$ Journal Officiel de création des associations, sous-préfecture de Millau, août 2007.
} 
Although this appraisal draws upon a single case, the overarching rationale that led to undermining unarticulated opposition and lacking numbers was based on values such as public interest, objectivity and rational argumentation, which are at the basis of the professional code of practice (CEC, 1996). Such a case clearly shows that public inquiries can regulate marginal adaptation of wind power projects in local contexts, but that they are not the procedure through which the density/authorization of wind parks is currently regulated and certainly not the way through which non-opposable landscapes could be taken into account.

Overall, the procedures attached to the assessment of permits prioritize the scenic and opposable landscape and do not seem to regulate properly the density of wind power projects.

\section{- A planning scheme: layers as an "administrative landscape"}

Aveyron wind power planning was supposed to offset the shortcomings of authorization procedures and provide developers and the administration with strategic guidance. The design of the scheme started with a synthesis of available surveys including a mapping of "constraints and sensibilities" (SIEDA, 2001 and 2002) based on a classification of natural areas (e.g., biotope protection areas, Natura 2000 areas, classified biological sanctuaries, ZNIEFF ${ }^{12}$, UNESCO biosphere sanctuaries) and on "highly sensitive areas" as listed in the PNRGC Charter (e.g., wetlands, dry grasslands, woods, canyons and valleys, agricultural lands, etc. $)^{13}$. Birdlife and landscape were two important dimensions further elaborated and a source of dissension, enticing, for instance, the LPO to leave the MISAP because it was denied absolute protection of the most sensitive bird areas.

Landscape was approached together with architectural heritage in a way that implicitly set up a dichotomy between exceptional (classified, protected) and ordinary landscapes. Regulatory constraints were first mapped on the basis of extended state-declared delimited areas, leading to the inclusion of 10-km buffer perimeters around a few urban and historical landmarks (Rodez, Millau, Villefranche, Conques, Najac). Tensions within the MISAP emerged when it came to landscape characterization. In a precedent survey, the CAUE (CAUE 12, 2001) had divided Aveyron into six "landscape entities" defined by their historical/cultural/natural dimensions. This representation was considered by part of the MISAP, especially the SDAP, as "not sufficiently manageable" to provide a basis for the new wind power scheme. This was partly because of their scale (too small) and partly because of their encompassing definition (which did not allow assessment of wind power impact). A private landscape company was commissioned to define new landscape entities with which to associate heritage values (Carrés Verts, 2002). In general, the work proceeded through physical description and the application of a dichotomy between heritage landscapes and other landscapes. The company divided the territory into (23) small entities, which were then pooled together into (4) landscape types according to

\footnotetext{
${ }^{12}$ Launched in 1982, ZNIEFF (Zones Naturelles d’Intérêt Ecologique Faunistique et Floristique) have the aim of identifying and describing areas presenting high biological capacities and a good state of conservation.

${ }^{13}$ http://www.territoires-durables.fr/agenda21Detail.asp?pk_agenda21=19\#le_projet
} 
“objective” criteria (e.g., geomorphology, land use) and associated with heritage values. Open fields and plateaus were considered as less sensitive to wind power developments than hilly "bocage" or woody landscape. Heritage values were elaborated on the basis of regulatory protection and reputation, as attested by field work and bibliographic survey: "emblematic" landscapes were those famous beyond Aveyron; "remarkable" landscapes were landmarks in Aveyron. Needless to say, the result (cf.Table 3) appeared simplistic to the parties involved, particularly to the CAUE, which pointed out a "mathematical take on the landscape" through "strange classifications" (interview by the authors). The classification was further simplified by the DDE, which decided to delete non-characterized landscapes (i.e., to retain only the bold categories in Table 3).

Table 3: Warning index for wind power development (1 low, 2 medium, 3 strong)

\begin{tabular}{|l|l|l|l|l|}
\hline & Plateau with bocage & Plateau of the Grands Causses & Hilly bocage & Woody hills and valleys \\
\hline Emblematic & Non-existent & $\mathbf{3}$ & $\mathbf{3}$ & $\mathbf{3}$ \\
\hline Remarkable & 1 & $\mathbf{2}$ & $\mathbf{2}$ & $\mathbf{2}$ \\
\hline Non-characterized & 1 & 1 & 2 & 2 \\
\hline
\end{tabular}

Buffer zones up to 10-km wide were introduced along major tourism itineraries, namely highways and national roads, so as to preserve the appearance of Aveyron landscapes for passing tourists. As the DDE stated quite frankly, priority was given to the visual dimension of landscape:

"In Aveyron, we chose to say it was good for wind power to be far away, to be lost in the countryside ... our orientation was to say that it is good for wind power not to be seen by a lot of people [...]" (DDE, interview by the authors, August 23, 2006)

The resulting scheme was divided into four types of zones (cf. Figure 1), ranging from compatible with wind power developments (1) to incompatible (4), and depending on the number of layers raising "strong issues". As stated by the SDAP, this number was "roughly indicative of the number of administrations which took issue with a project in each zone" (interview by the authors). The document was released in April 2005. While it proved useful for administrative co-ordination, its scope as a planning document remained limited for a set of reasons. 
Figure 1: "Framework for wind power development" (April, 2005)

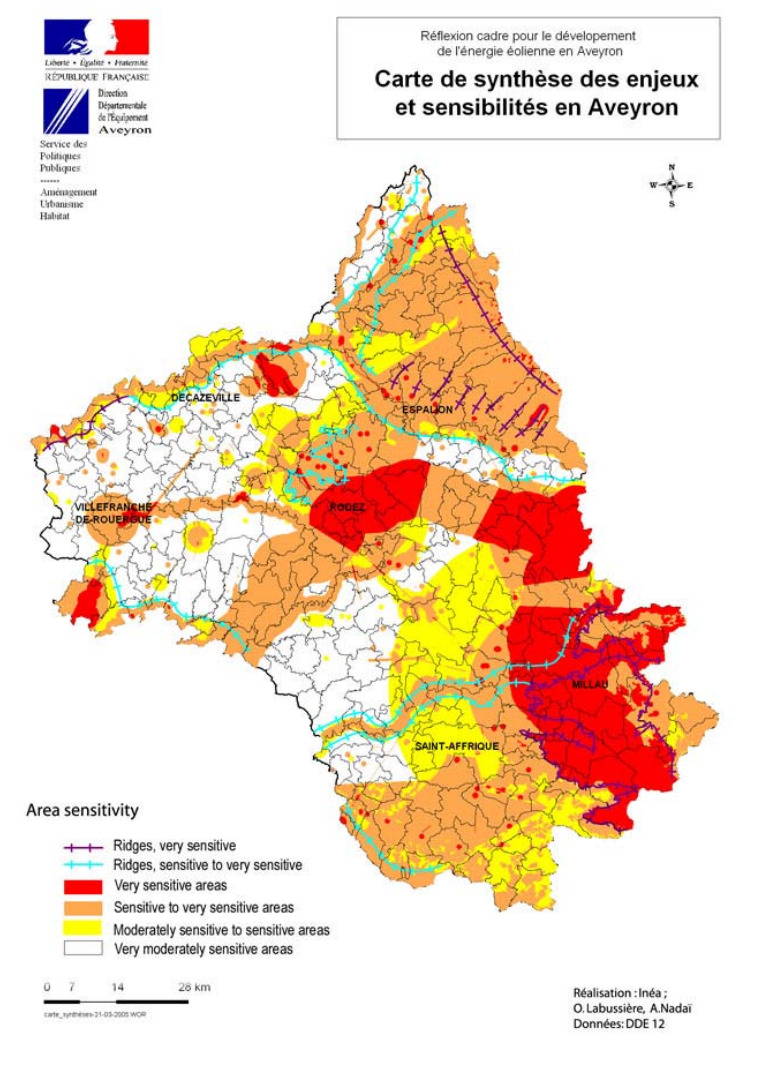

Figure 2: Effectiveness of the wind power scheme (projects under development as of May 2006)

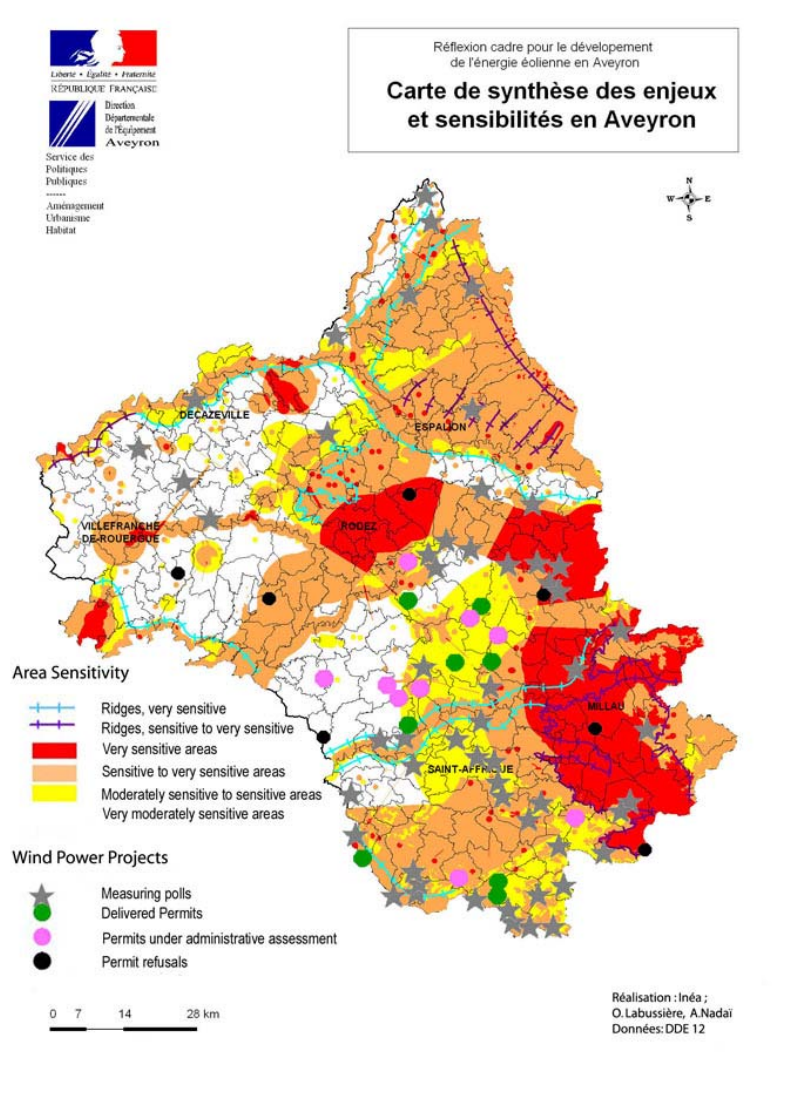

By the end of 2006, figures showed that no permit had been granted in incompatible zones (4), but developers had been and still were mainly considering zone (3) for project development because these were the zones with the best wind potential (cf.Fig. 2). Apart from this, the planning scheme already had some major shortcomings. First, due to its construction, it failed to take account of non-opposable landscapes, since these landscapes rarely enjoy a wide reputation. Second, it failed to regulate the densities of projects. While developers seemed to avoid zone (4), the concentration of projects in the other zones had not been properly regulated by the scheme, as demonstrated by the case of Mont Lévezou (zone 1) where opposition emerged because of the proliferation of projects under development. Third, it did not regulate co-visibilities with unfavorable zones (4). A recent example had been provided by a project located in zone (1), Vezins-de-Lévezou on the Mont Lévezou, which impacted visually on the Aveyron Valley, classified as emblematic (zone 4). According to the SDAP, the case of Vezins indicated a possible stalemate in the overall algorithm of visual protection underlying the scheme. Fourth, the principle of adding layers showed itself to be counterproductive in that it did not convey a relevant hierarchy to developers. As one of the parties involved in the MISAP commented, adding layers "confused constraints that could be overcome on a case by case basis at the level of the project with more general heritage/landscape constraints concerning landscape as a whole” 
(interview by the authors). Aubrac landscape, a well-preserved plateau in the North West of Aveyron, regarded as "emblematic" by the SDAP, had been a case in point. In Aubrac, protection got blurred in the addition of layers and ended up in zone (3) in the final scheme (instead of 4, as according to the SDAP), conveying to developers the message that they could plan developing wind power projects in this area, albeit with possible difficulties. Fifth, the configuration of the Aveyron electricity grid was not taken into account. Whereas grid development potentially allows for 75 MW extra, about 190 MW had already received a permit by the spring of 2006. Finally, the scheme proved static. Since 2000, the date at which the design of the scheme was initiated, the size of the turbines has increased (almost two-fold) and their capacity to generate power in less windy conditions has been greatly improved. Turbines have become more visible and have a different, more imposing presence in the landscape. Profitable wind power developments can now be considered in areas where they were not 7 years ago. As a result, only 2 years after its release, the Aveyron planning scheme was dated and limited in regulating local wind power.

From 2005 onwards, as the WPDZ implementation deadline approached (i.e., July 2007) and its design was underway, there was a political window of opportunity to recast wind power development and to possibly fix past errors.

\section{WPDZ implementation and the emergence of decentralized planning}

Wind Power Development Zones could potentially instigate a bottom-up dimension in French wind power planning. Indeed, the regulatory texts stipulate that WPDZ should be designed on a pluricommunal level and take account of a set of territorial and environmental factors such as existing wind power projects, grid connection potential, landscape and wildlife issues (Ministry of Energy, 2005; Ministry of Environment, 2006). As is the case for authorization procedures, WPDZ approval is under the authority of the departmental Prefect, where it is supposed to benefit best from the input of local actors (e.g., regional authorities, inter-communalities, community mayors and other territorial actors such as "Parc Naturel Regionaux"...) while remaining under the authority of the State ${ }^{14}$. WPDZ are also associated with the benefits of fixed tariff and with a wind power tax, which is a type of business tax redistributing wind power benefits to the members of the zones (communities and intercommunalities $)^{15}$. The goal of these incentives is to provide local representatives with an economic motive to co-ordinate and plan wind power at a relevant scale. While this is what the national framework suggests, the implementation of WPDZ at the local level has followed many routes.

In Aveyron, the design of WPDZ started under a double umbrella. On the one hand, the Aveyron administration decided on WPDZ perimeters within which it required local councillors to coordinate

\footnotetext{
${ }^{14}$ For an analysis of the reasons, see Nadaï 2007a.

${ }^{15}$ Article 1609 quinquies $\mathrm{C}$ of the Tax Code.
} 
wind power developments. The administration delimited five possible WPDZ areas ${ }^{16}$ (cf . fig. 3). Notwithstanding the unchanged administrative and hierarchical style, WPDZ clearly induced a shift in scale, if not a change in approach. Grid connection was considered, as demonstrated by fig. 3. Actual landscapes were also taken into account, since the administration relied on the different massifs (mountain ridges; see below) in order to outline what it called "massifs WPDZ". Yet WPDZ perimeters still followed the outline of the wind power scheme and the ministerial field services saw the result as a "complementing the Aveyron planning scheme".

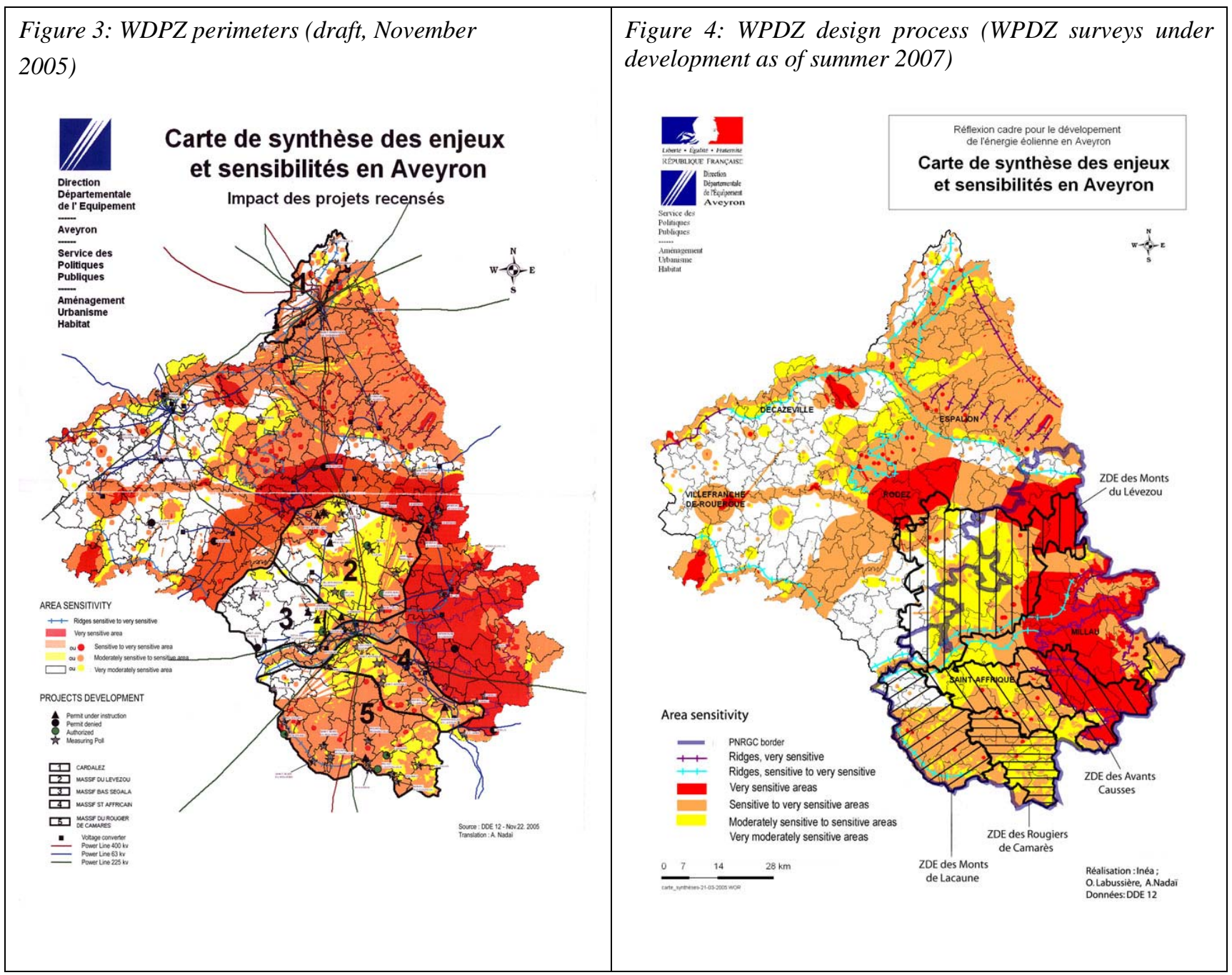

Several steps endowed this WPDZ scheme with institutional and political power. The first was the June 2006 implementation circular (Ministry of Environment, 2006). The second was the rejection of the first WPDZ application, over the summer of 2006, on the grounds that landscape was not sufficiently taken into account and that the application covered only one village - Salles Curan in Mont Lévezou, which had received permit approval for an important wind power project (87 MW).

${ }^{16}$ Carladès (1), Massif du Lévezou (2), Massif du Bas-Ségala (3), Massif du St-Affricain (4) et Massif du Rougier de Camarès (5). 
This administrative notification clearly meant that the Averyon administration would not be keen on approving "project WPDZ” - i.e., WPDZ consisting only in re-using lay-out plans, locations and impact studies that had already been put forward and agreed upon for specific projects. In the fall of 2006, the Aveyron prefect invited all mayors from Mont Lévezou to "pursue an inter-communal process that is likely to lead to establishing a WPDZ on the scale of the massif and of the landscape entity of Lévezou, so as to avoid cumulative visual impacts which might in the end lead to the rejection of wind power”17. In May 2007, a new WPDZ application by Salle Curan was finally approved provided that it would soon be extended to all the communities which are part of the massif and landscape entity of Lévezou. What this suggests is that the WPDZ furnished the administration with a political opportunity to fix past errors and shift the burden to local mayors. Significantly, the administrative mapping of WPDZ was the first planning document for wind power to feature the Aveyron grid (cf. fig 3).

The second umbrella under which WPDZ have been developed is the Parc Naturel Régional des Grands Causses. Immediately after the first wind power project (2000), the PNRGC had suggested planning wind power on the scale of the massifs, which it defined as "sets of ridges forming entities that are both natural and human" (PNRGC, interview by the author). The idea was discarded by the prefecture as being too complicated, since massifs could overlap administrative divides. According to the PNRGC, it was precisely because wind power benefits and impacts overlap administrative borders (communal and inter-communal) that the "massif" scale was relevant for regulating the cumulative impacts and the densities of wind power. Such a framework was also meant to entice collective action and provide local mayors with negotiating power. Instead of having individual communities competing for wind power revenues and projects, developers could be put in competition according to their ability to take account of the local context. In this way, issues of landscape and proximity could be reintroduced into the process. At least this is what the PNRGC was advocating.

Since 2000, the PNRGC has been following the work of the MISAP, but its role has remained limited to providing information. The design of WPDZ was the occasion for the PNRGC to endorse a more central role in wind power planning, in accordance with its philosophy. As of fall 2007, four WPDZ processes were under way or envisaged, more or less covering all non-(4) zones from the administrative scheme in the PNRGC (cf. fig. 4). Two of these processes (i.e., "Rougiers de Camarès" and "Monts Lévezou") resulted in the design of WPDZ without the PNRGC being in time to follow the process. The other two (i.e., "Avants Causses" and "Monts de Lacaune”) are only now emerging and the Park is associated with them: the "Avants Causses" is made up of two inter-communalities currently looking for funding through the PNRGC and the DIREN; the "Monts de Lacaune" consists of four inter-communalities currently being approached by the PNRGC. A major step has been the recent issuing of a PNRGC guidance document for WPDZ development (PNRGC, 2007), intended to

${ }^{17}$ Official mailing to the Lévezou mayors. 
complement the June 2006 circular. Landscape, grid connection and existing wind power projects are some of the criteria listed in the PNRGC guidelines, but the emphasis is put on four additional and important dimensions: the development of WPDZ on a relevant landscape scale (one not necessarily fitting the administrative borders but rather reflecting "territorial coherency"), the actual landscape entities and the massifs; the pluri-communal dimension and the sharing of wind power revenue (through the setting of a wind power tax) so as to lessen economic issues and make room for genuine planning choices; the joint agreement with all interested parties in a "shared landscape approach" (setting up a steering committee that is representative of the parties concerned, planning regular meetings throughout the process and including the local population); and the extension of the notion of landscape to non-classified and non-visual elements so as to take account of people's uses of their local landscape (landscape should be approached through description and by surveying the perceptions and uses of landscape by the local population). The process is structured in several phases which are meant to address most of the shortcomings of the "monumental”/“visual”/“administrative” landscapes that we have indicated. The process ends up with a positive and concerted definition of wind power zones instead of the current "negative" planning and "Decide-Announce-Defend" pattern of authorization procedures. The comprehensive approach to landscape, notably by enrolling the local population, their perceptions and their uses of the landscape from the beginning of the process onwards, should support a qualification of "non-opposable" landscapes, which were the landscapes missing in the administrative approach. As the PNR states, the goal is "[...] to take account of nonclassified landscapes such as the paths that locals love, and above all to keep people informed so that they are not caught off guard at the end of the process" (interview by the authors). Last but not least, co-visibilities and densities have a better chance of being regulated. Indeed, the perimeter of the study is congruent with the far-reaching visual impacts of wind power. Co-visibilities are no longer approached in a top-down manner based on abstract computer simulations, but by first identifying the landscape elements that are valued by the local populations in order to explore co-visibilities among these elements, the turbines and the scenic landscape. Most importantly, funding is offered to intercommunalities which agree to follow these recommendations.

The PNRGC's action is welcomed by the DIREN, which is cooperating with it in fund raising. Yet there remain two uncertainties in the process. The first is the extent to which the prefecture will welcome WPDZ proposals that do not fit the outline of the administrative scheme. The second and more important one relates to the difficulty of planning a posteriori. Accepted projects hold out promises of income for the rural communities. Seeing their projects brought back for discussion or postponed is very difficult for these communities. It raises distributive issues, as for instance has been the case with the design of the Monts Lévezou WPDZ, which the Saint Affricain inter-communality was supposed to join but did not for these kind of reasons. Success largely depends on the new projects being put on hold by the prefecture and on the capacity of the administration to depart from its usual planning style. 


\section{Discussion}

We introduced this paper by stating that industrial wind turbines were rarely compatible with existing landscapes. We suggested that approaching wind power development with the tool-kit of landscape protection might miss the point, since it left few chances for the emergence of new energy landscapes. Revisiting the Aveyron case, we pointed to four types of landscape representations in wind power planning.

Figure 5: Decentralized planning experiments (via WPZD) are conditioned by types of landscape representations

\begin{tabular}{|c|c|c|}
\hline $\begin{array}{r}\text { Windpower } \\
\text { regulation at local } \\
\text { level }\end{array}$ & $\begin{array}{l}\text { WPZD, a national } \\
\text { planning framework } \\
\text { opening opportunities for } \\
\text { decentralized planning }\end{array}$ & $\begin{array}{l}\text { Types of } \\
\text { landscape } \\
\text { representations }\end{array}$ \\
\hline $\begin{array}{r}\text { Protecting institutional } \\
\text { ("opposable") landscapes } \\
\text { (route 2) }\end{array} \rightarrow$ & $\begin{array}{c}\text { Recycling } \\
\text { protective planning } \\
\text { (e.g. « Project WPDZ ») }\end{array}$ & $\begin{array}{l}\text { - “monumental” } \\
\text { - “visual” } \\
\text { - “administrative” }\end{array}$ \\
\hline & 4 & \\
\hline $\begin{array}{r}\text { Looking for new compatibilities } \\
\text { between }\end{array} \rightarrow$ & $\begin{array}{l}\text { Decentralizing, } \\
\text { opening up } \\
\text { the planning process } \\
\text { (re-composing the social) }\end{array}$ & $\begin{array}{l}\text { - “non-opposable” } \\
\text { (e.g. “proximity” landscape) }\end{array}$ \\
\hline
\end{tabular}

The "monumental" and the "visual" landscape fell short as categories for regulating wind power densities/co-visibilities because of their emphasis on the scenic landscape. What we called the "administrative landscape", that is, the practice of adding layers that reflect the administration's approach to landscape rather than the landscape per se, also proved inadequate, even in protecting scenic landscapes. The Aveyron public inquiries, although they were supposed to be places for public expression, proved to be only marginal landscape adjusters because of their late position in the process and the weight given to public interest and rational argumentation. None of these representations proved able to enroll into wind power planning what we called "non-opposable" landscapes; that is, the landscapes which are not already qualified/classified by regulatory/administrative categories. The reasons for this lay both in concept and network. Conceptually, these representations tend to "freeze" landscape by being both quantitative and static. In Aveyron, quantification has operated in many ways: early refusal to consider non-administrative landscape entities because they would be too 
heterogeneous (e.g., refusal of the "massifs" approach proposed by the PNRGC); reduction of landscapes to their morphology and land use (i.e., "hilly bocage”); translation of landscape types into warning indices; and addition of heterogeneous layers as if they were homogenous quantities. In the end, the process boiled down to an aggregation of administrative-type layers in that zone indices (“ 1 ” to "4") became "indicative of the number of administrations a developer might find in his way" (SDAP). Authoritarian administrative decisions and the implicit rationale of public interest was part of the design of these representations - e.g., giving priority to tourism and locating wind power in the rural areas so as to support the Aveyron economy. As Flyvbjerg (1998) states, and as the narrowing down of the Aveyron MISAP illustrates, rationality goes hand in hand with power: imposing a selfreferring representation only works in a restricted arena. To this extent, the evolution of the Aveyron planning process is illustrative of a process that has taken place in many French regions. Wind power planning was fairly innovative in its beginning: when turbines were still strange, local administrations set up very inclusive steering committees so as to benefit from all competences in assessing the first projects, but these committees tended to be cut back to the administration as procedures became routine. In the end, wind power planning became more open to developers than to other parties, somewhat reintegrating the usual French meso-corporatism in environmental policy, whereby access to policy-making is restricted to a set of corporations (Szarka, 2004, 2007).

In such a context, the WPDZ /PNRGC turn is all the more interesting as it re-opens the process to nonopposable landscapes and provides non-administrative parties with a genuine role in wind power planning. It amounts to a French version of decentralization, both in the concept and the networks underlying landscape representations. Although WPDZ provides a framework by which decentralization is made possible, joint agreement between all interested parties, "massif entities" and "proximity landscape" are not explicitly part of it. Their actual inclusion in Aveyron wind power planning is to the credit of the PNRGC. The change is still tentative, since no WPDZ have been completed, but the case demonstrates that changing landscape representation is dependant on decentralization, meaning that wind power planning is no longer entrenched in the local administration but dealt with in a process which includes local political actors and the local population. The encompassing dimension given to "proximity landscape" and "shared landscape approach" potentially paves the way for the emergence of new landscape representations.

The Aveyron case is critical because the past underestimation of grid connection constraint has placed WDPZ development under strong pressure. Yet the evolution from authoritarian administrative planning to incipient decentralization is paradigmatic and most French regions and departments are currently facing the same challenge. The DIREN are unanimously welcoming WPDZ as a good but late instrument, seeing in it a device that might confront local mayors with their responsibilities in wind power development. Town councillors are becoming key actors in wind power planning, since they are both the recipients of wind power benefits (through the wind power tax) and the steering 
agency for WPDZ development. Density, co-visibility and proximity issues demand competences in landscape analysis possessed neither by the administration nor the mayors. This fosters the involvement of new territorial actors in the policy process such as "Parcs Naturels Régionaux" or inter-communalities, and all this may initiate new approaches to landscape, as has been the case in Aveyron. As of the end of April 2007 (that is 10 months after their implementation started), $21 \mathrm{WDPZ}$ have been validated, amounting to 207-875 MW (floor - cap), and 50 WDPZ were under administrative consideration (no capacity communicated) (Observ'er, 2007a). This seems a low figure by comparison with the potential pipe capacity ${ }^{18}$, but the amount is equal to or more than the total growth in French wind power capacity in 2006. As the French government is not pushing for a sudden boost in wind power capacity, France will probably not suddenly become the match of Spain or Germany. It has been and still is up to the local administrations to elaborate their guidelines and assess their local wind power potential ${ }^{19}$. The installed capacity will continue to be steered by departments, where WPDZ might instigate a bottom-up dimension and provide wind power developments with greater legitimacy.

This sheds a new light on the French case. While it is true that the lock-in into nuclear energy does not provide the central government with incentives to guide wind power development (Szarka, 2007), the institutionalization of revenue sharing with local communities through taxes has undermined the power of local opposition. It is not inexistent, but it was not able to block wind power development as it did in other countries, such as the UK (Bell et al., 2005, Toke, 2005), because town councillors and mayors are recipients of part of the wind power benefits. The turn to WPDZ is then all the more significant as it might also entice councillors and mayors to open up the decision process.

While we have pointed to the potential of the new WPDZ approach, it is unfortunately not possible at the current stage of the process to comment on its substantive effects. One reason is the lack of accumulated data on this aspect; another is that new actor networks are still in the process of being formed, so that the outcome of the WPDZ process cannot yet be assessed.

Beyond the specifics of the Aveyron situation, the case also indicates the way in which technology has forced a change in landscape approach by overflowing the administrative framework due to its farreaching visual impacts. The need to decide from a distance and provide developers with clear strategic guidelines is probably one reason for the administrative tendency to "freeze" landscape into self-referring representations that may (at first sight) acquire a quantitative dimension. Quantitative indices commonly appear less debatable than qualitative ones. Yet the Aveyron story proves that wind

\footnotetext{
${ }^{18}$ Recent figures provided by RTE show that the current wind power capacity in the pipe amounts to about 11.1 to 13 GW (RTE, 2007).

${ }^{19}$ Of the 22 metropolitan DIREN interviewed by the authors, 13 could provide a figure for quantifying the local wind power potential; 4 said the potential was very limited without providing any figure, and 5 could not provide any assessment of their potential. As for the limiting factors, 13 indicated landscape, 5 grid connection potential, and 4 could not state any limiting factor.
} 
power extends beyond quantitative delimitations. Whatever the buffer zones implemented, wind power will be visible in most landscapes. In other words, visual protection or visual assessment, if it boils down to a pure metrics underlying a landscape planning algorithm (e.g., Möller, 2006), is doomed to failure with industrial wind power. Shifting to "proximity" or "shared landscape" is a way to reach beyond the metrics of visual landscape and make turbines part of new landscapes.

If new energy landscapes are to become "sustainable", new landscape representations have to emerge with the development of these energies. Certainly, affects in relation to turbines (McFadyen and Warren, this issue) become part of people's relation to their landscape and, as such, are steps on the way to new landscape representations. They might even be a channel through which planning could be approached so as to be renewed and to allow for genuine social re-composition (Labussière, 2007). In order to achieve this, they need to be discussed, processed and given form so as to be part of new landscape representations. "Proximity landscape" is one possible route that has been proposed by PNRGC in the case under scrutiny. Others have to be explored, bearing in mind that we are not dealing with ways of fitting turbines into existing contexts, but with ways of re-composing the social.

\section{Acknowledgements}

The authors would like to thank the "Conseil Français de l'Energie”, the French Ministry for the Environment (MEDAD - Program PDD “Paysage et Développement Durable”), the French Agency for the Environment and the Energy (ADEME), the Region Ile-de-France and the Centre National de la Recherche Scientifique (CNRS - Programme Interdisciplinaire pour l'Energie) for their financial support of this research.

\section{References}

Bell, D., Gray, T., Haggett, C., 2005. The Social gap in wind farm siting decisions : explanation and Policy response. Environmental Politics 14 (4), pp. 460-477.

Bender, B., 1998. Stonehenge : making space, Berg, Oxford.

Bigando, E., 2004, Entre le social et le sensible l'émergence d'un paysage ordinaire. Bulletin de l'Association de géographes francais, 81(2), pp. 205-218.

Breukers, S., Wolsink, M., 2007. Wind power implementation in changing institutional landscapes: An international comparison. Energy Policy, 35, pp. 2737-2750.

Burall, 2004, "Putting wind turbines in their place", Town and Country Planning, February, 60-63.

Carrés Verts, 2002. Volet paysager du plan de cohérence du développement éolien en Aveyron. Carrés Verts. Atelier Paysage, Environnement, Urbanisme.

CAUE 12, 2001. Les entités paysagères de l'Aveyron. Document de travail.

CNCE, 1996 Charte du Commissaire-Enquêteur, Compagnie Nationale des Commissaires enquêteurs, 30 mars, Montbéliard, France.

Coles R.W. and Taylor, J., 1993. "Wind power and planning: The environmental impact of windfarms in the UK”, Land Use Policy, July 1993

Cosgrove, D., Daniels, S. (eds), 1988. The iconography of landscape: essays on the symbolic representation, design and use of the past environments. Cambridge, Cambridge University Press.

Cowell R. and Strachan P.A., 2007, Managing Wind Power Deployment in Europe, European Environment, 17. 
Cowell, R. (in this issue). "Wind power, landscape and strategic planning - the construction of 'acceptable locations' in Wales"

Danielsen O., 1995. “Large-scale wind power in Denmark”, Viewpoint, Land Use Policy 12 (1) 60-62

Devine Wright, P., 2005. Local Aspects of UK Renewable Energy Development: Exploring Policy beliefs and Policy Implications, Local Environment, 10 (1), pp. 57-69.

Flyvbjerg, B., 1998, Rationality and Power: Democracy in Practice, Chicago university, university press of Chicago.

Haas, R. et al., 2004. How to promote renewable energy systems successfully and effectively. Energy Policy, 32, pp. 833-839.

Hirsch, E. and O'Hanlon, M. (eds), 1995. The anthropology of landscape : perspectives on place and space, Oxford, Clarendon Press.

Labussière O. (2007). Le défi esthétique en aménagement : vers une prospective du milieu. Le cas des lignes très haute tension (Lot) et des parcs éoliens (Aveyron et Aude) ; sous la dir. de Vincent Berdoulay : Thèse de doctorat : géographie et aménagement : Université de Pau et des Pays de l’Adour, 607 p.

Latour, B., 2003. The promises of constructivism, in Chasing Technoscience: Matrix of materiality", Don Idhe (ed.), Indiana University Press.

Latour, B., 2005. Reassembling the Social- An Introduction to Actor-Network-Theory, Oxford University Press.

Marvin, C., 1988. When technologies were new: Thinking about electric communication in the late nineteenth century, Oxford University Press.

McFadyen M., Warren C. (this issue) "Does community ownership affect public attitudes to wind energy? A pilot study from south-west Scotland"

McKenzie Hedger M., 1995. “Wind power: challenges to planning policy in the UK” Land Use Policy, July 1993

McLaren Loring, J., 2007. Wind energy planning in England, Wales and Denmark: Factors influencing project success, 35 (4), pp2648-2660.

Ministry of Economy, 2000b. Décret no 2000-1196 du 6 décembre 2000 fixant par catégorie d'installations les limites de puissance des installations pouvant bénéficier de l'obligation d'achat d'électricité, J.O nº 285 du 9 décembre 2000, p. 19550.

Ministry of Economy, 2001.Arrêté du 8 juin 2001 fixant les conditions d'achat de l'électricité produite par les installations utilisant l'énergie mécanique du vent, telles que visées à l'article $2-2^{\circ}$ du décret $\mathrm{n}^{\circ} 2000$ 1196 du 6 décembre 2000, published in the French JO November 21, 2001.

Ministry of Economy, 2006a. « Arrêté du 10 juillet 2006 fixant les conditions d'achat de l'électricité produite par les installations utilisant l'énergie mécanique du vent, telles que visées à l'article $2-2^{\circ}$ du décret $\mathrm{n}^{\circ}$ 2000-1196 du 6 décembre 2000.

Ministry of Economy, 2006b. Arrêté du 7 juillet 2006 relatif à la programmation pluriannuelle des investissements de production d'électricité, texte $\mathrm{n}^{\circ} 17 \mathrm{~J} . \mathrm{O} \mathrm{n}^{\circ} 158$ du 9 juillet 2006 page 10317.

Ministry of Energy, 2005. « Loi $\mathrm{n}^{\circ}$ 2005-781 du 13 juillet 2005 de programme fixant les orientations de la politique énergétique » J.O nº 163 du 14 juillet 2005 p.11570.

Ministry of Environment, 1993. LOI no 93-24 du 8 janvier 1993 sur la protection et la mise en valeur des paysages et modifiant certaines dispositions législatives en matière d'enquêtes publiques, J.O nº 7 du 9 janvier.

Ministry of Environment, 2006. « Dispositions relatives à la création des zones de développement de l'éolien terrestre », Circulaire du 19 Juin 2006, Paris.

Ministry of Interior, 2003. « Loi n 2003-590 du 2 juillet 2003 urbanisme et habitat », published in the French J.O n ${ }^{\circ} 152$ du 3 juillet 2003 p. 11176.

Möller Bernd, 2006. "Changing wind-power landscapes: regional assessment of visual impact on land use and population in Northern Jutland, Denmark”, Applied Energy, 83, 477-494.

Mukerji, C., 1997. Territorial ambitions and the gardens of Versailles, Cambridge : Cambridge University Press.

Nadaï, A., 2007a. "Planning”, "siting”' and the local acceptance of wind power: Some lessons from the French case. Energy Policy, Volume 35, Issue 5, May 2007, pp. 2715-2726. 
Nadaï, A., 2007b, Site ou l'émergence d’un paysage, in Lolive, J. et Blanc, N. (dir.) «Esthétique et Espace Public », Cosmopolitiques,15, pp.173-178. ${ }^{20}$

Observ’er, 2007a. «Le Journal de l'éolien », Systèmes Solaires, l’Observateur des Energies Renouvelables », Hors série, 1, July, Paris.

OECD, 2006. Territorial Review of France, OECD publishing, April, Paris.

Olwig, K., 2002. Landscape, Nature and the Body Politic: From Britain's Renaissance to America's New World, University of Wisconsin.

Pasqualetti, M., 2000. Morality, space and the power of wind energy landscape. Geographical Review, 90 (3), pp. 381-394.

PNRGC, 2007. Zone de Développement de l'éolien dans le PNR des Grands Causses, Cahier des charges précisant les modalités du chapitre relatif à l'étude patrimoniale et paysagère du dossier de Z.D.E.

Préfecture de l'Aveyron, 2005. Réflexion cadre pour un développement de l'énergie éolienne en Aveyron, Avril. Préfecture de l'Aveyron, 2007. “Communiqué à la Presse : Développement de la production d'énergie éolienne dans le département de l'Aveyron - Etat des lieux », Communiqué de Presse Services du cabinet, Bureau de la communication interministérielle, 8 octobre, Rodez.

Roger, A., 1997. Court traité du paysage, Paris, Gallimard.

Selman P., 2007, Learning to Love the Landscapes of Carbon-Neutrality, paper presented at the ESF Exploratory Workshop, CIRED, Emerging Energies, Emerging Landscapes: Revisioning the past, constructing the future, June, Paris.

SIEDA, 2001. Projet Eolien. Rapport de stage réalisé par Delphine Gilard (Institut national des sciences appliquées de Toulouse - Département de génie des procédés industriels) pour le compte du SIEDA.

SIEDA, 2002. Mise en place d'un plan de cohérence de développement de l'éolien en Aveyron : Plan Eole 12 ; réalisé par Victor Afonso pour le compte du SIEDA.

Smith A., 2007 "Emerging in between: The multi-level governance of renewable energy in the english regions". Energy Policy, Volume 35, pp. 6266-6280.

Szarka, J., 2004. Wind Power, Discourse Coalitions and Climate Change: Breaking the Stalemate. European Environment, 14 (6), pp. 317-330.

Szarka, J., 2006. Wind power, policy learning and paradigm change, Energy Policy, 34 (14), pp. 3041-3048.

Szarka, J., 2007. Why is there no Wind Rush in France. European Environment, 17 (5), pp. 321-333.

Toke, D., 2005. Explaining wind power planning outcomes: some findings from a study in England and Wales, Energy Policy;33:1527-39.

Toke, D., Breukers S., Wolsink, M. 2008. Wind power deployment outcomes: How can we account for the differences? Renewable and Sustainable Energy Reviews, Volume 12, Issue 4, Pages 1129-1147.

Warren, C.R., Lumdsen, C., O’Dowd, S., Birnie, R., 2005. Green On Green : Public Perceptions of Wind Power in Scotland and Ireland. Journal of Environmental Planning and Management, 48 (6), pp. 853 - 875.

Wolsink, M., forthcoming, "Near-shore Wind Power - Protected Seascapes, Environmentalist Attitudes, and the Technocratic Planning Perspective”, XX , in this issue.

Woods, M., 2003. Conflicting environmental visions of the rural: windfarm development in mid Wales. Sociologia Ruralis, 43 (3), pp. 271-288.

\section{Acronyms}

ADEME (Agence De l’Environnement et de la Maîtrise d’Energie);

CAUE (Conseil d'Architecture, d’Urbanisme et d'Environnement);

DDE (Direction Départementale de l’Equipement);

DIREN (Direction Régionale de l’Environnement);

DRIRE (Direction Régionale à l’Industrie, la Recherche et l’Environnement); 20 For the unpublished English version of the paper, see Nadaï 2004, "In the making of landscape: site", paper presented at the world
conference of the Society for Social Studies of Science, Paris, Ecoles des Mines, Paris. 
(C) 2008 Elsevier Ltd - Nadaï, A., Labussière, O. (2009) Wind power planning in France (Aveyron), from state regulation to local planning, Land Use Policy 26(3): 744-754.

LPO (Ligue de Protection des Oiseaux);

MISAP (Mission Interservices de l’Aménagement et du Paysage);

PNRGC (Parc Naturel Régional des Grands Causses);

SDAP (Service Départemental de l’Architecture et du Paysage);

SIEDA (Syndicat Intercommunal d’Electricité du Département de l’Aveyron). 